\title{
$\beta$-クリプトキサンチンの抗ストレス作用における性差の可能性
}

\author{
海野けい子, ${ }^{*, a}$ 野田誠紀, ${ }^{b}$ 川崎洋平, ${ }^{b}$ 井口和明, ${ }^{a}$ 山田 $\quad$ 浩 ${ }^{b}$
}

\section{Possible Gender Difference in Anti-stress Effect of $\beta$-Cryptoxanthin}

\author{
Keiko Unno, ${ }^{*, a}$ Shigenori Noda, ${ }^{b}$ Yohei Kawasaki, ${ }^{b}$ Kazuaki Iguchi, ${ }^{a}$ and Hiroshi Yamada ${ }^{b}$ \\ ${ }^{a}$ Department of Neurophysiology, School of Pharmaceutical Sciences, University of Shizuoka; 52-1 Yada, Suruga-ku, \\ Shizuoka 422-8526, Japan: and bivision of Drug Evaluation \& Informatics, School of Pharmaceutical \\ Sciences, University of Shizuoka; 52-1 Yada, Suruga-ku, Shizuoka 422-8526, Japan.
}

(Received January 19, 2016; Accepted March 28, 2016)

\begin{abstract}
Beta-cryptoxanthin $[\beta$-CRX, (3R) $-\beta, \beta$-caroten-3-ol] is a provitamin $\mathrm{A}$ and a potent antioxidant that is abundant in Satsuma mandarin orange (Citrus unshiu MARC.), which is the most popular fruit in Japan. The anti-stress effect of $\beta$-CRX on humans was evaluated in fifth-year university students during both routine daily life at the university and at pharmacy practice. The study design was a double-blind group comparison and participants $(n=20$; female 12 , male 8$)$ were randomly assigned to $\beta$-CRX-rich orange juice or placebo ( $\beta$-CRX was removed from orange juice) groups. $\beta$ CRX or placebo juice $(125 \mathrm{~mL}$, once a day, after breakfast) were consumed from $10 \mathrm{~d}$ prior to the pharmacy practice and continued for $10 \mathrm{~d}$ into the practice period. To assess participants' anxiety, the state-trait anxiety inventory test was carried out before the pharmacy practice. Salivary $\alpha$-amylase activity (sAA) was measured as a marker of sympathetic nervous system activity. In the placebo-group, sAA in the evening (post-practice sAA) tended to be higher than sAA in the morning (pre-practice sAA) during both routine daily life at the university and during pharmacy practice. In the $\beta$ CRX-group, the increase of post-practice sAA was suppressed in females. These results suggested that $\beta$-CRX has an anti-stress effect, at least, in females.
\end{abstract}

Key words_ anti-stress effect; $\beta$-cryptoxanthin; gender difference; mandarin orange; pharmacy practice; salivary amylase activity

緒言

適度なストレスはよい刺激を生体にもたらすが, 長期にわたるストレスや過度のストレスは，様々な 疾病の発症や進行 ${ }^{1-4)}$ 及び老化に深く影響を及ぼす ことから, ${ }^{5)}$ 日々の生活の中で過剰なストレス応答 を抑制し，ストレス蓄積を予防することは重要であ る. 食品あるいは食品由来の成分の中から, 抗スト レス作用を示すものが科学的に明らかとなれば，食 生活の改善を通して，ストレス関連疾患やストレス に起因する老化促進の予防に結びつくと考えられ る。温州ミカンに豊富に含まれている色素成分の $\beta$-クリプトキサンチン ( $\beta$-cryptoxanthin; $\beta$-CRX) は, ビタミン $\mathrm{A}$ 前駆体としての作用6)のほかに, 強 い抗酸化活性を示すことから加齢に伴う脳の機能低

$a$ 静岡県立大学薬学部統合生理学講座， $b$ 静岡県立大学 薬学部医薬品情報解析学講座

*e-mail: unno@u-shizuoka-ken.ac.jp
下を予防すること, ${ }^{7)} 2$ 型糖尿病，メタボリックシ ンドローム, 脂肪肝, 骨粗鬆症, 更年期障害, 乳が ん等のリスク軽減に関与することが報告されてい る. ${ }^{8-14)}$ また，雄マウスに縄張り意識を利用したス トレスを負荷すると副腎が有意に肥大するが, ${ }^{15)} \beta$ $\mathrm{CRX}$ 摂取群では副腎の肥大が抑制され， $\beta$-CRX は 抗ストレス作用を示すことが実験動物において見い 出された（未発表デー夕）。そこで本研究では， $\beta$ CRXの新たな作用として「抗ストレス作用」に着 目し臨床研究を行つた。

生体がごの程度ストレスを感じているのかを評価 する 1 つの方法として，唾液アミラーゼ活性（salivary $\alpha$-amylase activity; sAA）を指標とする方法を 用いた。 sAA は交感神経一副腎䯣質系（sympathetic nervous-adrenomedullary system; SAM system) の 神経活動を評価するための指標になると考えられて いる. ${ }^{16-18)}$ SAA は生理的及び心理的ストレスに反応 して速やかに活性が上昇し, ${ }^{19-22)}$ 感度よく非侵襲的 


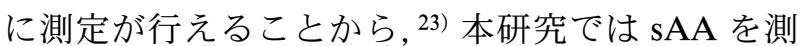
定することにより， $\beta$-CRX の抗ストレス作用を評 価した.

\section{方法}

1. 臨床研究参加者 静岡県立大学薬学部 5 年 生の健康ボランティア 20 名 (女性 12 名, 男性 8 名) を対象とした。参加する被験者には，研究担当者よ り研究内容について十分に説明を行い，本人の自由 意思による文書同意が得られてから臨床研究を実施 した。参加する被験者に対するプライバシーは十分 に配慮した．個人情報に関しては連結可能な匿名化 を行い，個人情報が外部に漏洩しないよう細心の注 意を払つた。被験者は $\beta$-CRX を高めたミカン果汁 摂取群 $(\beta$-CRX 群) と, ミカン果汁から $\beta$-CRX を 除いたプラセボ果汁摂取群（プラセボ群）との 2 群 に割付け，二重盲検群間比較試験を行った。割付は 静岡県立総合病院創薬育薬研究室データマネジメン トセンターで実施した。

本研究は世界医師会「ヘルシンキ宣言」（2013 年 10 月フォルタレザ改訂）及び厚生労働省「人を対 象とする医学系研究に関する倫理指針」(2014 年 12 月公布）に則り，参加する被験者の人権及び福利を 十分に配慮して実施した。本研究の開始にあたって は, 事前に静岡県立大学研究倫理審査委員会の承認 を得た（承認番号 26-50）。また本研究は，UMIN 臨床試験登録システムに登録した (UMIN00001716S)。

2. 臨床研究の実施本臨床研究は 2015 年 4 月 30 日から 5 月 19 日までの 20 日間実施した。こ の期間中，前半の 10 日間（4/30-5/9） は大学での 生活期間であり，後半の 10 日間 $(5 / 10-5 / 19)$ が病 院・薬局での実務実習期間であった。臨床研究開始 前に, 状態不安の程度の指標として STAI テスト [Form-X，三京房侏］を行った。STAI テストは状 態不安・特性不安に関する自記式質問紙で，その妥 当性が十分に検討されている. ${ }^{24)}$ 本研究では, 状態 不安に関する 20 項目の質問を実施した。評価点が 高いほど，現時点での不安の程度が高いことを意味 する。

臨床研究期間中, 起床後並びに実習終了後に, 毎 日 sAA を測定しストレスの指標とした。また， $\beta$ $\mathrm{CRX}$ を高めたミカン果汁あるいはプラセボ果汁 (125 mL) のいずれかを，1 日 1 回朝食後に摂取し
た。被験者は試験期間中，ミカン果汁あるいは $\beta$ CRX を含むと思われる食品の摂取を控えた。また 毎日，体調，主観的ストレス，実習の達成度，食事 摂取の有無，睡眠時間を記録した。体調は「非常に よい」から「不良」までの 5 段階で記録した。主観 的ストレスは，実習終了時に感じた状態を visual analogue scale (VAS) で自己評価した。チェック 表にある 0-10までの目盛りをつけた線分上で，全 くストレスを感じなかった場合を「0」とし，非常 に強いストレスを感じた場合を「10」として，実習 終了時の自分の精神状態にあった位置に印をつけ た．実習の達成度は「十分できる」から「不十分」 までの 5 段階で自己評価した。

3. 唾液アミラーゼ活性（sAA）の測定生理 的なストレス状態は， sAA を測定することにより 評価した。これは基質である 2-chloro-4-nitrophenyl-4- $O-\beta$-D-galactopyranosylmaltoside が，競合 阻害作用を示す maltose 存在下で唾液アミラーゼに よって加水分解され, 反応ストリップ [ニプロ侏］ が白色から黄色に変色することを利用している. ${ }^{23)}$ 起床時及び実習終了時に，専用チップで唾液を採取 しアミラーゼモニター [ニプロ怢］を使用して測定 した.アミラーゼが 1 分間に還元糖 $1 \mu \mathrm{mol}$ を産生 する活性の単位を 1 U とした (NC-IUBMB, 1992). 20 日間の試験期間の中で，大学での生活及び病 院・薬局で実習を行った日の sAA 值を，解析に使 用した。

4. ミカン果汁 $\beta$-CRX を高めたミカン果汁 は， 1 本（125 mL）のボトル中にミカン 3 個分の $\beta$-CRX が含まれている市販の製品 [アシタノカラ ダ，侏えひめ飲料]を使用した。プラセボ飲料は， 遠心及び限外濾過膜による処理により $\beta$-CRX を除 いた試験用ミカン果汁 [秼えひめ飲料］を用いた。 ミカン果汁中の $\beta$-CRX の濃度は $3.30 \mathrm{mg} / 125 \mathrm{~mL}$ であった。一方プラセボ飲料中の $\beta$-CRX の濃度 は，検出限界 $(0.008 \mathrm{mg} / 100 \mathrm{~g})$ 以下であった。本 試験ではミカン果汁及びプラセボ飲料はいずれも白 色の容器に入っているものを使用し，被験者には区 別がつかないようにした。

5. 統計処理被験者背景の集計において, 連 続型のデータは平均值士標準誤差を示した。 sAA を目的変数として，二元配置分散分析により比較を 行った。さらに, Tukey-Kramer 法による多重比較 
を行つた．sAAの変化量については，プラセボ及 び $\beta$-CRX 群間で分散分析とともに $t$ 検定を行っ た。すべての仮説検定において，有意水準は $5 \%$ と した。なお統計処理は $\mathrm{SAS}^{\circledR} 9.4$ (SAS Institute Inc., Cary）を使用して行った.

\section{結果}

1. 大学及び実務実習時の sAA の変化 本臨 床研究期間に被験者らは大学で 2-6 日間生活し, 病 院・薬局で 7-8 日間の実習を行つた。それらの日の 起床時及び実習終了時に測定した sAA の全デー夕 を用い，群間で比較を行つた。その結果プラセボ群 では，大学での生活及び病院・薬局での実習終了後 の sAA（post-sAA）は，起床時の sAA（pre-sAA） に比べ有意ではないが，高い傾向にあることが示さ れた [Fig. 1(a), $p=0.588]$ 。大学での sAA の変化 と, 病院・薬局での実務実習中での $\mathrm{sAA}$ の変化に は違いは認められなかった。 $\beta$-CRX 群でも同様に pre-sAA に対し post-sAA が高い傾向にあることが

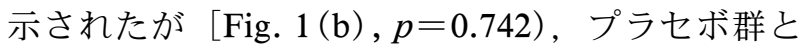
同様にそれらの変化には大学及び実務実習とで違い が認められなかった。

\section{2. $\beta$-CRX 摂取の効果 $\quad \beta$-CRX 群について,} 男性と女性に分けて $\mathrm{sAA}$ 值の変化を調べた。その 結果女性の場合プラセボ群では，大学及び病院・薬 局での post-sAA は起床時の pre-sAA に比べ高まる 傾向にあったが [Fig. 2(a), $p=0.649], \beta$-CRX 群 では post-sAA 值の上昇が抑制されていた。一方男 性では pre-sAA 值がプラセボ群と $\beta$-CRX 群で異 なっていたが，プラセボ群及び $\beta$-CRX 群で postsAA が高い傾向にあった [Fig. 2(b), $p=0.646$ ．

大学及び実務実習とで sAA の変化に違いが認め られなかったことから両者のデー夕をまとめ，男性 と女性に分けて pre-sAA と post-sAA の変化量につ いて分散分析を行った。 その結果，プラセボ群及び $\beta$-CRX 群で有意差が認められた（女性 $p=0.036$, 男性 $p=0.047$ ）。そこで pre-sAA に対する post$\mathrm{sAA}$ の増加の程度について検定を行った結果，プ ラセボ群の女性及びプラセボ・ $\beta$-CRX 両群の男性 では sAA が有意に増加していたが（プラセボ群女 性 $16.6 \pm 4.1$ ，プラセボ群男性 $7.5 \pm 2.4, \beta$-CRX 群 男性 $18.4 \pm 4.8, p<0.003), \beta$-CRX 群の女性では 有意な増加は認められなかった $(5.7 \pm 3.0, p=$
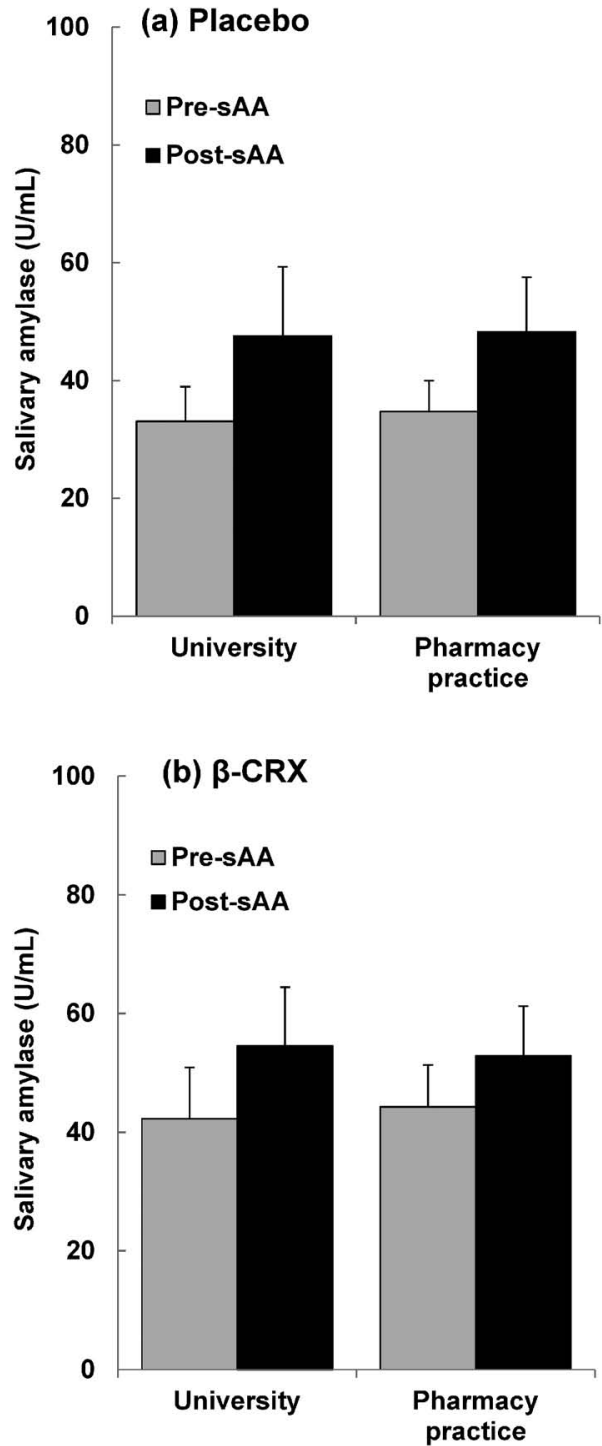

Fig. 1. Salivary $\alpha$-Amylase Activity (sAA) of the Participants during Daily Life at the University and at Pharmacy Practice

(a) Placebo; (b) $\beta$-CRX group. sAA was measured in participants at the university for $10 \mathrm{~d}$ prior to pharmacy practice for $10 \mathrm{~d}$. The study design was a double-blind group comparison and participants $(n=20$; female 12 , male 8 ) were randomly assigned to the placebo group ( $\beta$-CRX was removed from orange juice) or to the $\beta$-CRX-rich orange juice group. sAA was measured in participants in the morning after waking up (pre-practice, gray bar) and in the evening after practice (post-practice, black bar). The levels of sAA on unassigned days were not included in the analysis. Data are expressed as mean + S.E.M.

0.052)。これらのことから，女性では $\beta$-CRX 摂取 により post-sAA の増加が抑制されることが示され た.

主観的ストレスについて男性と女性に分けて，大 学及び病院・薬局でのストレス感に違いがあるか調 べた。主観的ストレスは，大学での生活及び病院・ 薬局での毎日の実習終了時に記述された全デー夕を 用い，群間で比較を行った。その結果女性では病 

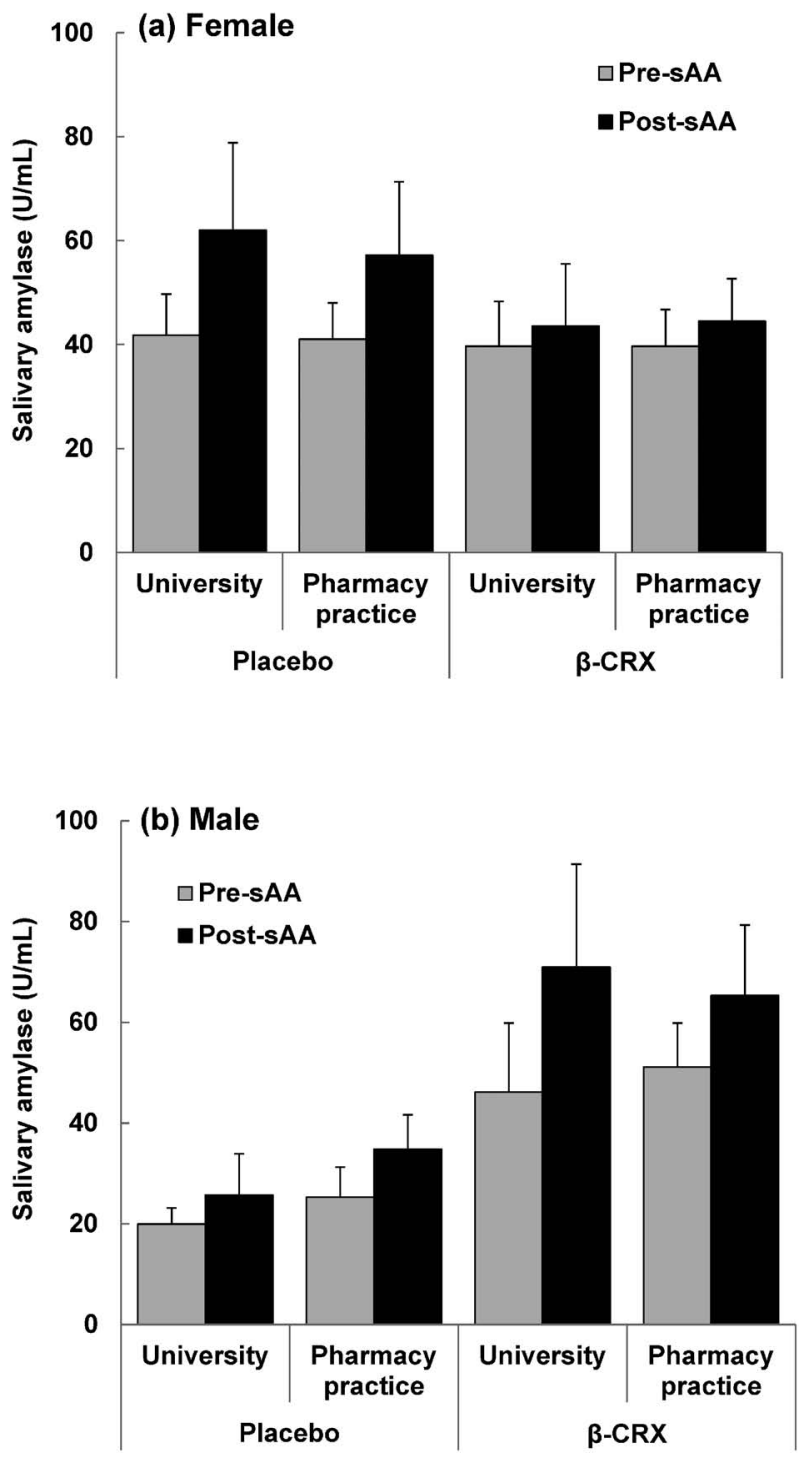

Fig. 2. The Difference in sAA between Females and Males

The level of sAA in females (a, $n=12$; placebo $6, \beta$-CRX 6 ) was expressed as pre-practice sAA (gray bar) and post-practice sAA (black bar) during university life and pharmacy practice. Similarly, sAA in males (b, $n=$ 8 ; placebo $4, \beta$-CRX 4) was expressed during university life and pharmacy practice. Data are expressed as mean + S.E.M.

院・薬局実習時にプラセボ群に比べ $\beta$-CRX 群で主 観的ストレスが抑制される傾向にあった（Table 1)。一方男性においては， $\beta$-CRX 摂取の効果はみ られなかった。主観的ストレスにおいても， $\beta$ CRX 摂取の効果に女性と男性とで違いがある可能 性が示唆された。

STAI 值は，臨床研究開始前に各被験者が 1 回 行ったテスト結果を用い, 群間で比較を行つた。健 康状態及び睡眠時間は，大学での生活及び病院・薬 局での毎日の実習終了時に記述された全データを用 い，群間で比較を行った。実習の達成度は，病院・
薬局での実務実習終了時に記述された全デー夕に基 づき，群間で比較を行った，その結果，状態不安の 程度を示す STAI 值，健康状態，実習の達成度，睡 眠時間の平均值は，女性・男性間，並びにプラセ ボ・ $\beta$-CRX 群で有意な違いは認められなかった (Table 1).

3. sAA 值の個人差とストレス感受性 sAA には個人差があることから，男性と女性に分けて， 大学での生活及び病院・薬局実習時の pre-sAA 及 び post-sAA について各被験者の平均值を求め, pre-sAA と post-sAA の関係を調べた。その結果プ ラセボ群及び $\beta$-CRX 群の両者において, pre-sAA が高い人ほど post-sAA も高いことが明らかとなつ た (Fig. 3; a, $p<0.001 ; \mathrm{b}, p=0.007)$ ここのことか ら pre-sAA が高い人ほど，ストレスを感じ易いこ とが示された。しかし pre-sAA が高い人でも $\beta$ CRX を摂取していた女性では，プラセボ群に比べ post-sAA が低いことが示された [Figs. 3(a) and (b); a, $\mathrm{y}=1.827 \mathrm{x}-16.09 ; \mathrm{b}, \mathrm{y}=0.683 \mathrm{x}+16.89]$ ] 一 方男性ではプラセボ群と $\beta$-CRX 群の間で pre-sAA の分布に違いはあるものの, pre-sAA と post-sAA との相関性には大きな違いはみられなかった [Figs. $3(\mathrm{c})$ and (d); c, $\mathrm{y}=1.066 \mathrm{x}+6.169 ; \mathrm{d}, \mathrm{y}=$ $1.340 \mathrm{x}+2.936]$ 。このことから，女性では $\beta$-CRX 摂取により post-sAA の増加が抑制されることが示 された.

Post-sAA の值と主観的ストレスとの相関性を比 較した結果, $\beta$-CRX 摂取群の女性では $\mathrm{sAA}$ が高い 被験者ほど主観的ストレスが高く，有意な相関性が 見い出された [Fig. 4(b), $p=0.040]$ 。一方プラセ ボ群では主観的ストレスの值に比べ, sAA が高い 值を示す被験者がいたことから，有意な相関性は認 められなかった [Fig. 4(a), $p=0.466]$.

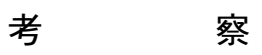

1. 実務実習におけるストレス 通常 $\mathrm{SAA}$ は 起床時に低く, ${ }^{25)}$ 日中の活動状況に従い值が上昇す ること, ${ }^{26-28)}$ またストレスがほとんどない環境下で は，sAA はほとんど変化しないことが報告されて いる. ${ }^{29)}$ 実務実習が開始された初期（2011 年）の頃 に行われた研究では, 実務実習時には大学での生活 時に比べ，sAA並びに主観的ストレスが有意に高

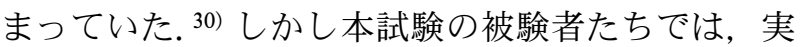


Table 1. STAI, Subjective Stress and Other Data of Female and Male Participants

\begin{tabular}{ccccccc}
\hline \hline \multirow{2}{*}{ Practice } & \multicolumn{2}{c}{ Female } & & \multicolumn{2}{c}{ Male } \\
\cline { 3 - 4 } \cline { 6 - 7 } & & Placebo & $\beta$-CRX & & Placebo & $\beta$-CRX \\
\hline \multirow{2}{*}{ Number } & & 6 & 6 & & 4 & 4 \\
\hline \multirow{2}{*}{ STAI } & & $38.00 \pm 2.31$ & $42.00 \pm 4.07$ & & $38.00 \pm 4.56$ & $39.25 \pm 6.61$ \\
\hline \multirow{2}{*}{ Subjective stress } & University & $4.54 \pm 0.18$ & $4.04 \pm 0.97$ & & $3.91 \pm 0.84$ & $4.98 \pm 1.22$ \\
& Pharmcy & $5.27 \pm 0.82$ & $4.26 \pm 0.88$ & & $4.86 \pm 1.11$ & $6.00 \pm 0.66$ \\
\hline \multirow{2}{*}{ Physical condition } & University & $2.82 \pm 0.13$ & $2.57 \pm 0.21$ & & $2.78 \pm 0.11$ & $2.35 \pm 0.51$ \\
& Pharmcy & $2.55 \pm 0.19$ & $2.45 \pm 0.25$ & & $3.07 \pm 0.28$ & $2.25 \pm 0.48$ \\
\hline \multirow{2}{*}{ Sleep time } & Pharmcy & $2.86 \pm 0.25$ & $2.57 \pm 0.39$ & & $2.93 \pm 0.33$ & $2.43 \pm 0.49$ \\
\hline & University & $5.98 \pm 0.33$ & $6.25 \pm 0.20$ & & $5.88 \pm 0.30$ & $7.10 \pm 0.50$ \\
& Pharmcy & $6.23 \pm 0.17$ & $6.11 \pm 0.16$ & & $5.91 \pm 0.25$ & $6.91 \pm 0.38$ \\
\hline
\end{tabular}

Each data represents mean \pm S.E.M.

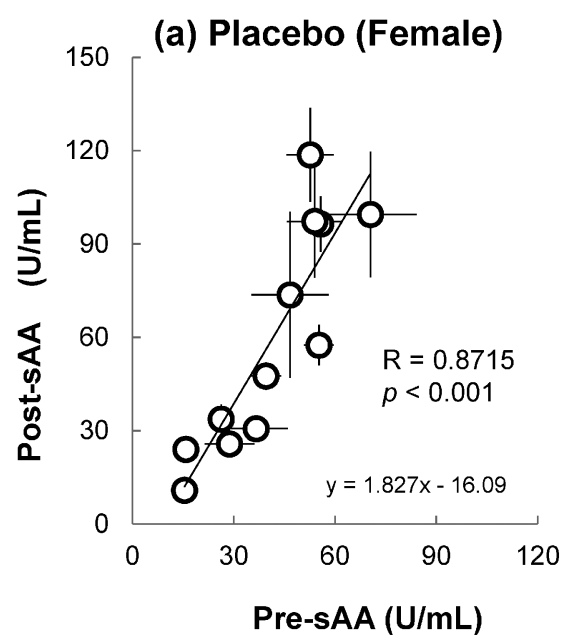

(b) $\beta$-CRX (Female)

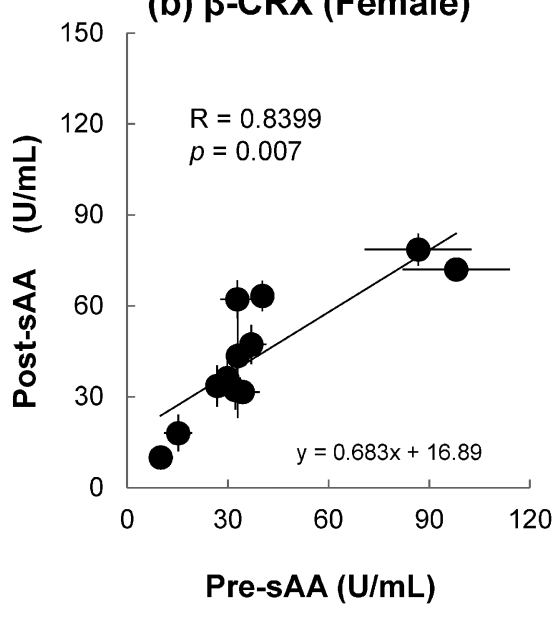

(d) $\beta$-CRX (Male)

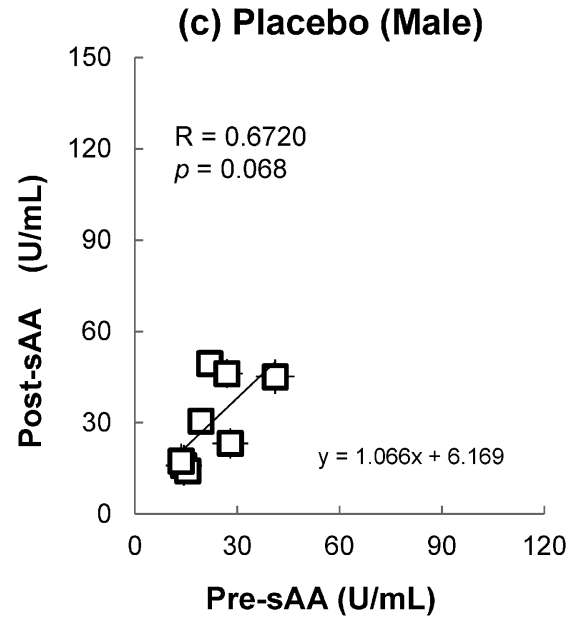

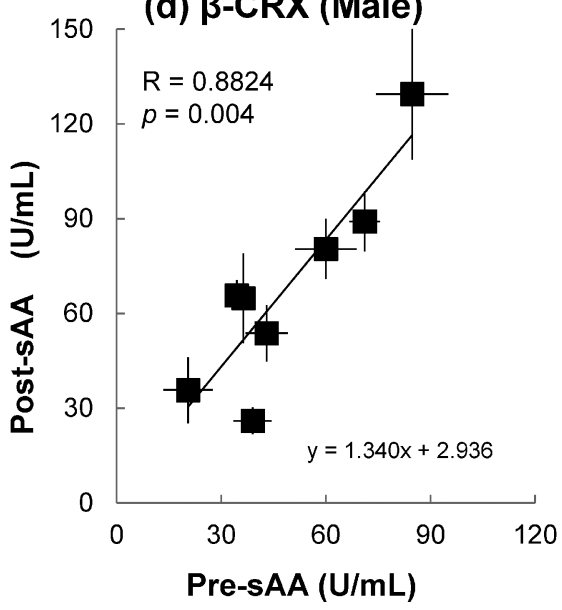

Fig. 3. Correlation between Pre- and Post-practice sAAs

(a) Female placebo-group; (b) female $\beta$-CRX-group; (c) male placebo-group; (d) male $\beta$-CRX-group. Each point of sAA, which represents the mean value of each participant, was calculated from sAA during university life and pharmacy practice. Data are expressed as mean \pm S.E.M. 

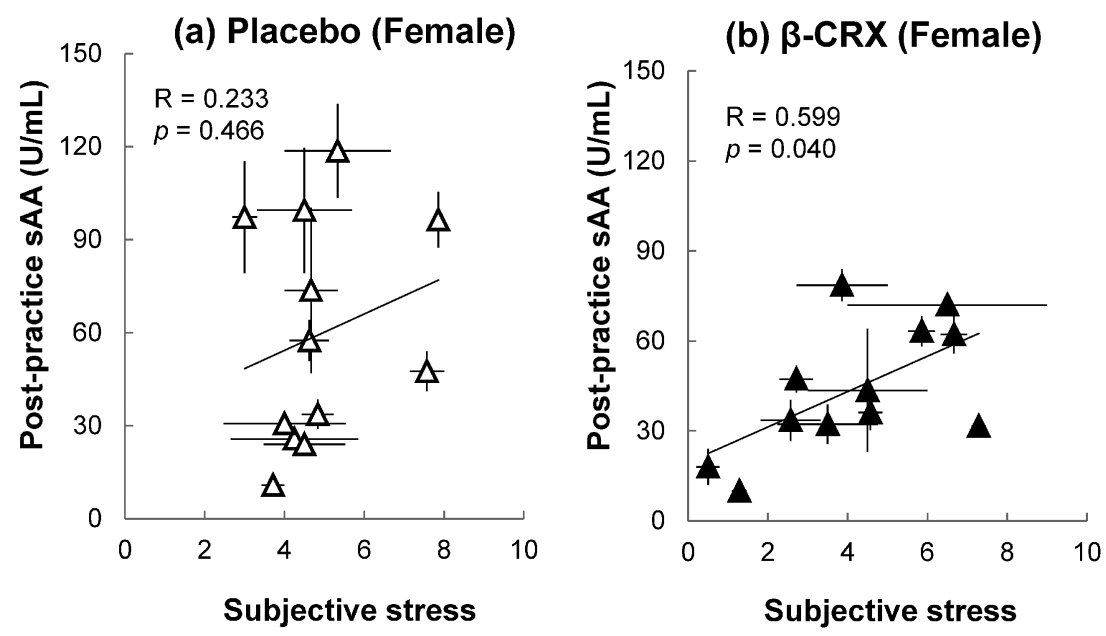

Fig. 4. Correlation between Post-practice sAA and Subjective Stress Female placebo-group (a), and female $\beta$-CRX-group (b). Data are expressed as mean \pm S.E.M.

務実習時に sAA 並びに主観的ストレスが有意に変 化するには至らなかった。 また，大学での生活と実 務実習中での sAA の変化は同程度であったことか ら，両者でのストレスの程度にはほとんど違いがな かったことが示された．被験者が異なることもある が, 実務実習を開始した初期に比べ, 学生も病院・ 薬局の指導薬剤師にも余裕が出てきていることが, 実務実習のストレス軽減につながっていると考えら れる。

2. $\boldsymbol{\beta}$-CRX の抗ストレス作用における性差 女性及び男性被験者の両者において, pre-sAA と post-sAA の間に非常に高い相関性があることが認 められ，pre-sAAが高い人ほどストレスを感じ易い 人であることが示された。しかし $\beta$-CRX の抗スト レス作用を調べている中で，女性の被験者では post-sAA の増加が抑制され，女性では $\beta$-CRX 摂取 によりストレスが軽減されることが示唆された。一 方男性では $\beta$-CRX 摂取による有意な効果が認めら れなかつたが, 本研究では被験者数が少ないため更 なる検討が必要である.

血清中のプロビタミン $\mathrm{A}$ カロチノイド（ $\alpha$-及び $\beta$-カロテン， $\beta$-CRX）量は女性に比へ，男性では

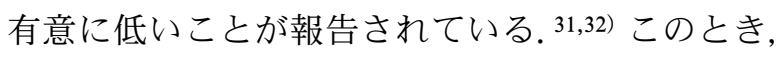
プロビタミン A ではないカロチノイド (ルテイン, ゼオキサンチン及びリコペン）量には女性・男性間 で違いはみられていないことから， $\beta$-CRX を含む プロビタミン $\mathrm{A}$ カロチノイトに関してのみ, その 吸収に性差があると考えられている。このような違
いが， $\beta$-CRX の抗ストレス作用においても関与し ている可能性が推察される.

3. 主観的ストレスと sAA sAA は生理的及 び心理的ストレスに応答して変化することが報告さ れている. 19-22) これまでに, 緑茶に含まれるアミノ 酸の 1 つであるテアニンについて抗ストレス作用を 評価した結果, sAA, 主観的ストレス, 及び不安感 の指標である STAI 值との間には有意な相関関係が あることを見い出し, sAA がストレス感受性の個 人差の指標となること，また主観的ストレス及び STAI 值の測定は重要な補助デー夕となることを示 した. ${ }^{30)}$ 本研究においても, sAA の個人差並びに朝 夕での変化を利用した評価は，ストレス指標として 優れた方法であることが示唆された。

また $\beta$-CRX 摂取群の女性では, テアニン摂取の ときと同様に, post-sAA の変化と主観的ストレス との間に有意な相関性が認められた。一方プラセボ 群では, 主観的ストレスの值に比べ sAAが高い值 を示す被験者がいたことから，実習時には被験者が 思っている以上に身体のストレス応答は高まってい たと考えられる， $\beta$-CRX 摂取により女性では身体 の過剰なストレス応答が抑制されていたことが示唆 されたが， $\beta$-CRXの作用に性差がある可能性につ いては，更なる検討が必要である.

結論

温州ミカンに豊富に含まれている $\beta$-CRX にはス トレスを軽減する効果があることが，女性被験者に 
おいて示唆された.

謝辞本研究は JSPS 科研費 $15 \mathrm{~K} 00828$ 及び果 樹試験研究推進協議会の助成を受け行われたもので す。また，本研究に協力して頂いた被験者の皆様に 感謝いたします。

利益相反＼cjkstart開示すべき利益相反はない.

\section{REFERENCES}

1) Kim J. E., Cho B. K., Cho D. H., Park H. J., Acta Derm. Venereol., 93, 387-393 (2013) .

2) Martocchia A., Stefanelli M., Falaschi G. M., Toussan L., Rocchietti March M., Raja S., Romano G., Falaschi P., Recent Pat. CNS Drug Discov., 8, 79-87 (2013) .

3) Hamer M., Psychosom. Med., 74, 896-903 (2012).

4) Bellinger D. L., Lubahn C., Lorton D., J. Immunotoxicol., 5, 419-444 (2008).

5) Unno K., Fujitani K., Takamori N., Takabayashi F., Maeda K., Miyazaki H., Tanida N., Iguchi K., Shimoi K., Hoshino M., Free Radic. Res., 45, 966-974 (2011).

6) Burri B. J., J. Sci. Food Agric., 95, 1786-1794 (2015).

7) Unno K., Sugiura M., Ogawa K., Takabayashi F., Toda M., Sakuma M., Maeda K., Fujitani K., Miyazaki H., Yamamoto H., Hoshino M., Biol. Pharm. Bull., 34, 311-317 (2011).

8) Sugiura M., Nakamura M., Ogawa K., Ikoma Y., Yano M., BMJ Open Diabetes Res. Care, 3, e000147 (2015).

9) Sugiura M., Nakamura M., Ogawa K., Ikoma Y., Yano M., Br. J. Nutr., 114, 1674-1682 (2015).

10) Ozaki K., Okamoto M., Fukasawa K., Iezaki T., Onishi Y., Yoneda Y., Sugiura M., Hinoi E., J. Pharmacol. Sci., 129, 72-77 (2015) .

11) Sugiura M., Yakugaku Zasshi, 135, 67-76 (2015).

12) Ni Y., Nagashimada M., Zhan L., Nagata N., Kobori M., Sugiura M., Ogawa K., Kaneko S., Ota T., Endocrinology, 156, 987-999 (2015).

13) Granado-Lorencio F., de Las Heras L., Millán C. S., Garcia-López F. J., Blanco-Navarro I.,
Pérez-Sacristán B., Domínguez G., Genes Nutr., 9, 428 (2014).

14) Pouchieu C., Galan P., Ducros V., LatinoMartel P., Hercberg S., Touvier M., Nutr. Cancer, 66, 980-988 (2014).

15) Unno K., Iguchi K., Tanida N., Fujitani K., Takamori N., Yamamoto H., Ishii N., Nagano H., Nagashima T., Hara A., Shimoi K., Hoshino M., Exp. Physiol., 98, 290-303 (2013).

16) Skosnik P. D., Chatterton R. T. Jr., Swisher T., Park S., Int. J. Psychophysiol., 36, 59-68 (2000).

17) Chatterton R. T. Jr., Vogelsong K. M., Lu Y., Ellman A. B., Hudgens G. A., Clin. Physiol., 16, 433-448 (1996).

18) Nater U. M., Rohleder N., Psychoneuroendocrinology, 34, 486-496 (2009).

19) Almela M., Hidalgo V., Villada C., van der Meij L., Espín L., Gómez-Amor J., Salvador A., Biol. Psychol., 87, 421-429 (2011).

20) Nater U. M., Rohleder N., Gaab J., Berger S., Jud A., Kirschbaum C., Ehlert U., Int. J. Psychophysiol., 55, 333-342 (2005).

21) Nater U. M., La Marca R., Florin L., Moses A., Langhans W., Koller M. M., Ehlert U., Psychoneuroendocrinology, 31, 49-58 (2006).

22) Rohleder N., Nater U. M., Wolf J. M., Ehlert U., Kirschbaum C., Ann. NY Acad. Sci., 1032, 258-263 (2004).

23) Yamaguchi M., Kanemori T., Kanemaru M., Takai N., Mizuno Y., Yoshida H., Biosens. Bioelectron., 20, 491-497 (2004).

24) Iwata N., Mishima N., Shimizu T., Mizoue T., Fukuhara M., Hidano T., Spielberger C. D., Ind. Health, 36, 8-13 (1998).

25) Adam E. K., Till Hoyt L., Granger D. A., Biol. Psychol., 88, 170-173 (2011).

26) Nater U. M., Rohleder N., Schlotz W., Ehlert U., Kirschbaum C., Psychoneuroendocrinology, 32, 392-401 (2007).

27) Wingenfeld K., Schulz M., Damkroeger A., Philippsen C., Rose M., Driessen M., Biol. Psychol., 85, 179-181 (2010).

28) Out D., Granger D. A., Sephton S. E., Segerstrom S. C., Psychoneuroendocrinology, 38, 367-375 (2013).

29) Yamaguchi M., Deguchi M., Miyazaki Y., $J$. Int. Med. Res., 34, 152-159 (2006) . 
30) Unno K., Tanida N., Ishii N., Yamamoto H., Iguchi K., Hoshino M., Takeda A., Ozawa H., Ohkubo T., Juneja L. R., Yamada H., Pharmacol. Biochem. Behav., 111, 128-135 (2013).

31) Olmedilla B., Granado F., Blanco I., Rojas-
Hidalgo E., Am. J. Clin. Nutr., 60, 106-110 (1994).

32) Xiang J., Nagaya T., Huang X. E., Kuriki K., Imaeda N., Tokudome Y., Sato J., Fujiwara N., Maki S., Tokudome S., Asian Pac. J. Cancer Prev., 9, 413-416 (2008). 